\title{
Intra-lingual Code Alternation in Arabic: The Conversational Impact of Diglossia
}

\author{
Abdel-Rahman Abu-Melhim \\ Department of English Language and Literature, Irbid University College, Al-Balqa’ Applied University, Irbid, Jordan
}

\begin{abstract}
The purpose of this paper is to investigate which varieties of Arabic educated speakers of both genders use when conversing with one another in informal conversational settings. The study specifically investigates the types of diglossic code-switches used, and the pragmatic functions of these various diglossic code-switches. It then investigates the informants' diglossic code-switching behavior and reasons for diglossic code-switching. The research was conducted using informants from Jordan, Iraq, Morocco, Egypt, and Saudi Arabia. Different groups of informants were arranged so that all combinations of informants within same-gender dyads were examined, with one female pair (one informant from each country) and one similar male pair from each applicable country. After the data were collected, salient portions of the audio-taped conversations were then transcribed and analyzed. It was observed that not once did subjects of this study use Classical Arabic as a linguistic medium during their taped conversations. Rather than relying primarily on CA or MSA, the informants employed a variety of accommodation strategies when conversing with one another, including the use of ESA, switching between ESA and the colloquial, and switching between colloquials.
\end{abstract}

Index Terms - code alternation, diglossic code-switching, communication accommodation theory, linguistic accommodation, Arabic dialects

\section{INTRODUCTION}

\section{Communication Accommodation Theory (CAT)}

It is a fundamental, substantiated, and well-established fact that the most important function of language is communication. Different speakers in any given speech community have various linguistic resources available to them depending primarily on the number of languages they speak and their level of awareness regarding the colloquial varieties of languages they know. These linguistic and communicative resources available to mono-lingual, bi-lingual, and multilingual speakers have been the subject of linguistic research especially in the past few decades (Bres \& Franziskus, 2014), (Bahous, Nabhani \& Bacha, 2013) and (Juma, 2013) for example.

According to CAT, there are two types of accommodation-CONVERGENT and DIVERGENT. Convergent accommodation refers to how one attempts to adapt one's communicative behavior to the other speaker-"a strategy whereby individuals adapt to each other's communicative behaviors in terms of a wide range of linguistic-prosodicnonverbal features including speech rate, pausal phenomena and utterance length, phonological variants, smiling, gaze, and so on" (Giles, Coupland, \& Coupland 1991, p.7). Since it acts to reduce differences, convergence can then be considered the expected behavior. On the other hand, in divergent accommodation, one attempts to accentuate the differences between oneself and the other speaker, instead of attempting to sound like him or her. Divergence, then, achieves its power, or shock value, by its exception to the expected behavior. Likewise, accommodation can be UPWARD or DOWNWARD. In this, one attempts to adapt to a language variety which may be either more or less prestigious, or more or less technically sophisticated (for example, a doctor and patient conversation), than one's own variety.

Basically, people attempt to converge for a number of reasons: evoking their listener's social approval, attaining more efficient communication, and maintaining positive social identities. Simply put, society frowns on difference: the more one is like the other, the more likely it is that the other person will look favorably on the first. This concept, called social integration, revolves around the terms IN-GROUP and OUT-GROUP-'us' and 'them.'

\section{a. Convergent Accommodation}

According to Giles, Coupland, \& Coupland (1991), "CAT proposes that speech convergence reflects, in the unmarked case, a speaker's or group's need (often unconscious) for social integration or identification with another... . Thus, convergence through speech and nonverbal behaviors is one of the many strategies that may be adopted to become more similar to another, involving the reduction of linguistic dissimilarities" (p.18). This concept, relating to our linguistic insecurity (Labov, 1972), can be illustrated with one unique study. Bell (1982, 1984) surveyed newscasters on New Zealand Broadcasting. Since stations are state-run, newscasters are employed by the government, and not by individual stations; as a result, some newscasters read the news on a number of different stations. These stations could be very different, running the gamut from country-western, to pop, to hard rock, to classical, appealing to different social groups and classes. In his survey, Bell found that these newscasters changed their speech styles according to the station they were broadcasting from, and showed that these broadcasters were unconsciously adapting their speech to what they thought were the speech styles of the listeners. 
Some everyday examples of speech convergence are the way we adapt our speech to those who are not as proficient in our language as we are - to children and foreigners. This also illustrates a second use for convergence-clarity of communication. For example, physicians use a terminology which may be incomprehensible to patients. To get the necessary information across, and get the patients to follow their instructions, the doctors must converge to the patients. In some cases, nurses may actually act as translators, or 'linguistic brokers' (Giles et al. 1987, p.22).

Misapplied convergence, called STEREOTYPICAL CONVERGENCE by Giles et al. (1987, p.18), can best be illustrated by how some caregivers speak to the elderly. In nursing homes, caregivers will often 'baby talk' to their patients based on their perceptions of these patients functional capability, regardless of the actual mental capabilities of these elderly people (Caporael, Lukaszewski, \& Culbertson, 1983).

\section{b. Divergent Accommodation}

The opposite side of convergence is divergence. In this, speakers go out of their way, to some degree consciously, so as to highlight or accentuate the difference, both linguistic and social, between themselves and out-group members. Sometimes speakers may even go as far as rephrasing an utterance by the other speaker in their own style, variety, and so on. Scotton (1986) calls this DISACCOMMODATION. In many cases, divergence is a group act.

We may diverge in order to direct the other speaker to moderate or modify their speech. If a speaker speaks too fast, we may speak unnaturally slowly. If the other speaker pauses too much, we may accentuate that to bring it to his or her attention. Finally, divergence may be a means to survival-one's own, or perhaps the survival of a relationship. Gottman (1982) found that spouses sometimes exhibit what he calls NEGATIVE AFFECT DE-ESCALATION. If their mate makes a negative remark, they may try to defuse a potential disagreement by positive remarks in response to the negative remarks - diverging from their spouse's style.

As all of the studies above show. A more common term for this phenomenon is code-switching or code alternation, and it is one major way to accommodate, especially in the interest of clearer communication.

\section{PURPOSE}

In this paper I investigate which varieties of Arabic educated speakers of both genders use when conversing with one another in informal conversational settings, in order to determine just how Educated Spoken Arabic (ESA) is used by these speakers, if or when they will use other varieties of Arabic, and what other accommodation strategies they will employ in informal conversational interactions.

The study specifically investigates the types of diglossic code-switches used, and the pragmatic functions of these various diglossic code-switches. It then investigates the informants' diglossic code-switching behavior and reasons for diglossic code-switching.

Moreover, it attempts to show the differences in accommodation strategies used by speakers of geographically and linguistically close varieties of Arabic when conversing with one another compared to the accommodation strategies used by speakers of geographically and linguistically distant varieties.

\section{MeTHODOLOGY}

\section{A. Informants}

The research was conducted using informants from Jordan, Iraq, Morocco, Egypt, and Saudi Arabia. These countries were selected principally due to geographical location. Two of the countries, Morocco and Iraq, were selected because they represent the extreme in geographical (as well as linguistic) distance-Morocco in the west, and Iraq in the eastapproximately 3,000 miles from Rabat, capital of Morocco, to Baghdad, capital of Iraq. Jordan was selected because of its central geographical position among the Arabic speaking countries-roughly 300 miles from Cairo, Egypt; 500 miles from Baghdad; 800 miles from Riyadh, capital of Saudi Arabia: and 2500 miles from Rabat.

Saudi Arabia was selected because of its geographical location and central position in Islam. Finally, Egypt was selected because it has not only a central position geographically and linguistically, but also socially. Until recently, Egypt has always been the most influential among the Arab countries, until Saudi Arabia's oil wealth gave it influence to equal Egypt's. Egypt is the most populous country in the Arab world, and has some of its oldest and most prestigious educational institutions.

The following informants were selected according to the above criteria. Further information about the background of the informants is summarized in table I below. Unless otherwise noted, the informant is Muslim. All informants have been given labels which consist of the first letter of their home country and their gender. 
TABLE I.

PERSONAL BACKGROUND OF INFORMANTS

\begin{tabular}{|l|l|l|l|l|l|l|}
\hline Informant & Age & Hometown & Rel. & Res. & Ed. & Parents Occ. \\
\hline JM & 29 & Irbid & M & US-2 1/2 & S/Ph.D Arch. & F=Contractor \\
\hline IM & 27 & Baghdad & M & US-3 & S/Ph.D Nuc. Eng. & F=Ret. Gov. Employee \\
\hline SM & 38 & Medina & M & US-8 1/2 & S/Ph.D. Ag. Ed. & F=Merchant \\
\hline MM & 32 & Rabat & M & $\begin{array}{l}\text { ON-1 } \\
\text { US-1 1/2 }\end{array}$ & S/MA Ag. Econ. & $\begin{array}{l}\text { F=Ret. Factory } \\
\text { Worker/Supervisor }\end{array}$ \\
\hline EM & 21 & Cairo & C & $\begin{array}{l}\text { US-4 } \\
\text { OA-8 }\end{array}$ & S/BS Comp. Sci. & $\begin{array}{l}\text { F=Physician } \\
\text { M=Physician }\end{array}$ \\
\hline JF & 24 & Irbid & M & $\begin{array}{l}\text { OA-8 } \\
\text { US-1 }\end{array}$ & BS, Pharmacology & F=Capt. Army (ret) \\
\hline IF & 24 & Kirkuk & C & US-12 & BS, Biochem. & F=Businessman \\
\hline SF & 26 & Mecca & M & US-10 & Some college & F=Businessman \\
\hline MF & 31 & Rabat & M & $\begin{array}{l}\text { ON-1 } \\
\text { US-3 }\end{array}$ & S/PhD Soil Sci. & F=Police Official \\
\hline EF & 19 & Cairo & C & $\begin{array}{l}\text { OA-8 } \\
\text { US-4 }\end{array}$ & BS Microbiology & $\begin{array}{l}\text { F=Physician } \\
\text { M=Physician }\end{array}$ \\
\hline
\end{tabular}

\section{B. Data Collection}

After the informants were selected, informal conversational situations were then arranged, attempting to keep the situation as natural and informal as possible. No particular topics were assigned for these situations. The purpose of arranging the conversations in this manner was to elicit data that would be representative of the informants' natural linguistic behavior in informal conversational interactions. After the data were collected, salient portions of the audiotaped conversations were then transcribed (see table II, below, for transliteration conventions). 
TABLE II.

GUIDE TO ARABIC PRONUNCIATION SOURCES: ABBOUD (1983); KAYE (1990)

\begin{tabular}{|c|c|c|c|c|}
\hline \multicolumn{3}{|c|}{ Arabic } & \multirow{2}{*}{ English example } & \multirow{2}{*}{$\begin{array}{l}\text { Sample Arabic word } \\
\text { transliterated, translated }\end{array}$} \\
\hline letter & name & symbol & & \\
\hline 1 & Palif & $\mathrm{a}$ & father & himaar (donkey); \\
\hline s & hamza & $?$ & [glottal stop] & raPs (head) \\
\hline ب ب & baa? & $\mathrm{b}$ & boy & kitaab (book) \\
\hline ت & taa? & $\mathrm{t}$ & toy & banaat (girls) \\
\hline$\dot{~}$ & $\theta$ aa? & $\begin{array}{l}\theta \\
\mathrm{t}\end{array}$ & thin & $\begin{array}{l}\text { Oaani (second) } \\
\text { taani }\end{array}$ \\
\hline 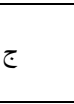 & jiim & $\begin{array}{l}\breve{j} \\
\bar{z} \\
\mathrm{~g}\end{array}$ & $\begin{array}{l}\text { judge } \\
\text { measure } \\
\text { got }\end{array}$ & $\begin{array}{l}\text { jamiil (pretty, handsome) } \\
\text { žamiil } \\
\text { gamiil }\end{array}$ \\
\hline$\tau$ & ћaa? & $\hbar$ & [voiceless pharyngeal fricative] & hatta (until) \\
\hline$\dot{\tau}$ & xxa? & $\mathrm{x}$ & [voiceless velar fricative] & Pax (brother) \\
\hline د & daal & $\mathrm{d}$ & dog & daar (house) \\
\hline ذ & ðaal & $\begin{array}{l}\partial \\
d \\
z \\
\partial \\
\end{array}$ & $\begin{array}{l}\text { then } \\
\text { den } \\
\text { Zen } \\
\text { [velarized voiced inter-dental fricative] }\end{array}$ & $\begin{array}{l}\text { haada (this) } \\
\text { haada } \\
\text { haaza } \\
\text { haaða }\end{array}$ \\
\hline $\mathrm{J}$ & raa? & $\mathrm{r}$ & run & rająa (returned) \\
\hline$j$ & zaay & $\mathrm{z}$ & zip & wazana (weighed) \\
\hline س & siin & $\mathrm{s}$ & seen & salaam (peace) \\
\hline ش & šiin & š & ship & $\begin{array}{l}\text { šabaab (youth, group } \\
\text { plural) }\end{array}$ \\
\hline ص ص & șaad & $\mathrm{s}$ & sun & șuuf (wool) \\
\hline 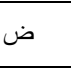 & daad & $\begin{array}{l}d \dot{d} \\
\dot{\partial}\end{array}$ & $\begin{array}{l}\text { [velarized voiced alveolar stop] } \\
\text { [see ð above] }\end{array}$ & $\begin{array}{l}\text { dufdaS ( frog) } \\
\text { dufda؟ }\end{array}$ \\
\hline b & țaa? & $\mathrm{t}$ & [velarized voiceless stop] & țaallb (student) \\
\hline ظ & ðаa? & $\begin{array}{l} \\
z\end{array}$ & $\begin{array}{l}\text { [see } ð \text { above] } \\
\text { [velarized voiced fricative] }\end{array}$ & $\begin{array}{l}\text { ðabi (gazelle) } \\
\text { zabi }\end{array}$ \\
\hline$\varepsilon$ & Sayn & ؟ & [voiced pharyngeal fricative] & Sayn (eye) \\
\hline$\dot{\varepsilon}$ & yayn & $\gamma$ & [voiced velar fricative] & ruul (ghoul) \\
\hline فن & faa? & $\mathrm{f}$ & fool & fill (elephant) \\
\hline ق & qaaf & $\begin{array}{l}\mathrm{q} \\
\mathrm{P} \\
\mathrm{k} \\
\mathrm{g}\end{array}$ & $\begin{array}{l}\text { [voiceless uvular stop] } \\
\text { [glottal stop] } \\
\text { king } \\
\text { gate }\end{array}$ & $\begin{array}{l}\text { qalam (pencil) } \\
\text { Palam } \\
\text { kalam } \\
\text { galam }\end{array}$ \\
\hline ك & kaaf & $\begin{array}{l}\mathrm{k} \\
\check{c}\end{array}$ & $\begin{array}{l}\text { king } \\
\text { church }\end{array}$ & $\begin{array}{l}\text { kalb (dog) } \\
\text { čalb }\end{array}$ \\
\hline J & laam & 1 & leave & lamasa (touched) \\
\hline 5 & miim & $\mathrm{m}$ & make & mawz (bananas) \\
\hline ن & nuun & $\mathrm{n}$ & now & nImr (tiger) \\
\hline . & haa? & $\mathrm{h}$ & hat & hunaa (here) \\
\hline 9 & waaw & $\mathrm{w}$ & wood & waadi (valley) \\
\hline ي & yaa? & $\mathrm{y}$ & yell & yad (hand) \\
\hline
\end{tabular}

Note 1: Doubled vowels (ex. $a a$ ) indicate increased length only.

Note 2: If more than one pronunciation is given, the most common alternate (regional colloquial) pronunciations are listed after the Standard (MSA) pronunciation.

a. The Data Collection Process

Each conversation, lasting approximately 30 minutes, was audio-taped using recording equipment unobtrusively situated, with the advance written consent of the informants.

Different groups of informants were arranged so that all combinations of informants within same-gender dyads were examined, with one female pair (one informant from each country) and one similar male pair from each applicable country, in the following combinations:

1) Jordanians and Egyptians

2) Jordanians and Saudi Arabians

3) Jordanians and Iraqis

4) Jordanians and Moroccans

5) Saudi Arabians and Egyptians

6) Saudi Arabians and Moroccans

7) Saudi Arabians and Iraqis

8) Egyptians and Moroccans

9) Egyptians and Iraqis

10) Moroccans and Iraqis. 
One last conversation, one with the males and one with the females, was then audio-taped with all informants of that gender together. There were a total of 22 group conversations (11 of each gender, each informant participating in 5 conversations) totaling approximately eleven hours of tape.

\section{b. Limitations}

While it would have been beneficial to have conducted studies of mixed gender pairs, it is an unfortunate reality of the Arab and Muslim societies that it would be difficult to carry out such a study. Some Arab males, especially Saudis, would outright refuse to allow their wives to participate, or find a diplomatic way to decline.

\section{LITERATURE REVIEW}

\section{Diglossic Code-switching}

There are specific reasons why the term CODE has been used here in the term 'code-switching' instead of LANGUAGE. First, it is a more neutral term than language, especially given the indistinct boundary between what constitutes a variety and a language. Second, in some countries there exists a linguistic phenomenon known as diglossia. One example of this would be in medieval France. The language of the Church and education (run by the Church) was Latin. Religious services were in Latin, university lectures were in Latin. However, the everyday language spoken on the streets of Paris was French, a vernacular descended from the Latin, but markedly different from it. Such situations still exist. In Haiti, French is the official language, the language of education and government. The everyday language is a Creole related to French, but very different from it. Another example is Switzerland. In the German-speaking cantons, the vernacular is a continuum of Swiss German varieties. However, the German used in government, education, and (officially) in the church is Standard German, or Hochdeutsch 'High German' - essentially the same Standard taught in the schools of Germany and Austria as well. One who speaks only Hochdeutsch would probably have extreme difficulty understanding the local varieties, as they are different enough from it as to almost constitute another language. These local varieties are as different from Hochdeutsch in one direction as Dutch and Flemish are different in another.

Diglossic code-switching (or multi-glossic code-switching) is, then, switching between varieties of the same language, where these varieties co-exist in the same speech community, each variety with its own definite function as is the case in Arabic today-for example, switching between the colloquial, or vernacular; the educated variety; and the Standard (written or Classical) variety (Ferguson, 1959).

The first major study of variation between Arabic colloquial varieties was carried out by Blanc (1960). He placed four native Arabic speakers (two from Baghdad, Iraq; one from Aleppo, Syria; and one from Jerusalem in a conversational situation. From his data, Blanc inferred the existence of a means of communicating across Arabic varieties. He used two terms: CLASSICIZING and LEVELING. "Classicizing referred to whether or not the phonology of the utterance included features which were Standard - speakers may modify utterances in the direction of slight formalization by the use of classicisms in certain specific cases" (p.83). For example, an Egyptian from Cairo would usually say ?aaði 'judge'; but in some cases, to be more formal, he or she might say qaaði. Leveling referred to the degree to which the syntax, vocabulary, or phonology of the speaker changed to resemble that of a higher prestige variety, sometimes up to the point of 'complete dialect substitution'. As Blanc (1960) says:

In certain situations, usually inter-dialectal contact, the speaker may replace certain features of his native dialect with their equivalents in a dialect carrying higher prestige, not necessarily that of the interlocutor.. .In general, leveling often takes place not so much in imitation of a specific dialect as in an attempt to suppress localisms in favor of features which are simply more common, more well known. (p.82)

Blanc gives examples of both phonological and vocabulary items. For phonology, he gives the example of the Palestinian villager who substitutes the more prestigious pronunciation (in this case Standard) $/ \mathrm{k} /$ for $/ \check{\mathrm{c}} /$, as in $\mathrm{kalb}$ for čalb 'dog'. For vocabulary changes, he gives the example of the word for another. The colloquial term is ?uxra, but in some cases the Palestinian villager would choose the more prestigious kamaan, even though ?uxra is actually derived from the Standard Paaxar and is closer to it. This illustrates Blancs point that leveling is not always synonymous with classicizing.

From these two categories, classicizing and leveling, Blanc (1960) developed five levels of 'terminological distinctions' between varieties of Arabic:

1. 'Plain colloquial' refers to any local dialect, within which the speaker may select 'informal' or 'mildly formal' features.

2. 'Koineized colloquial' is any plain colloquial into which leveling devices have been more or less liberally introduced.

3. 'Semi-literary' or 'elevated' colloquial is any plain or koineized colloquial that is classicized beyond the 'mildly formal' range.

4. 'Modified classical' is Classical Arabic with dialectal admixtures.

5. 'Standard classical' is any of a variety of Classical Arabic styles essentially without dialectal admixtures. (Blanc, 1960, p.85)

One thing Blanc's work did was to illustrate that the situation goes well beyond diglossia - to what this author has already referred to as multi-glossia (although for the sake of standardization the term diglossia will continue to be used as a cover term throughout this study). 
However, Holes (1991) and Mitchell (1986) make the point that using terms referring to educational levels to refer to levels of the colloquial can be confusing and misleading. A speaker who essentially is limited to the lower ranges of the colloquial may still have some education, and a person who operates at the highest levels of the colloquial, or even in the 'Standard.' may not have education much beyond high school, especially if that person comes from a background where the higher levels of the language are commonly used. For example, less educated servants in an upper-class household may be quite at home using the higher levels of the language. This might also hold true for someone from a religious family, which spends much of its time studying the Qur'an.

As Holes (1991) states, "most work done up until now in Arabic linguistics has centered around description of Arabic, paying little attention to explaining why variations exist and how they are used" (p.4). Holes (1991) also brings in what he calls HYBRIDIZATION, which is the term this study has adopted to refer to those constructions, in the discussion of the stylistic continuum. Essentially, hybridization occurs when a colloquial element is mated to a Standard feature. One example he gives is when the Egyptian dialectal tense marker $b$ - is prefixed to the Standard verb yuqbal, producing byuqbal 'is accepted.' He goes on to say that this hybridization is evidence of the co-existence and mutual accommodation of rival language systems [colloquial and Standard]. The more educated a speaker is, the more that speaker will make use of such hybrids. Holes also hypothesizes that "these hybridizations are rule-governed" (Holes, 1991, p.6). It might be noted that what Holes calls hybridization is in effect diglossic code-switching at the morpheme level; Eid (1982) clearly makes the point that this is code- switching, not borrowing. It might also be added that if this were borrowing instead of code-switching, then the Standard stem would be changed phonetically; it would be phonetically assimilated into the variety into which it was borrowed. Thus, the Standard stem would no longer be Standard if it were borrowed. Holes (1991) goes on to describe how the late president Gamaal Gabd Al-Naașir of Egypt uses the two levels of ArabicStandard and colloquial - in his speeches according to the tactical situation, the message he wishes to present. Naașir uses fușta (Standard Arabic) when he wishes to present messages which are 'abstract, idealized or metaphorical'. On the other hand, "when he wants to present messages which are concrete and physical, when he wants to personalize the issues, he uses the Saamiyya, or colloquial" (Holes 1991, p.17). In other words, a speaker's variety choices seem to be governed by three 'separate but overlapping' factors:

the status which he wishes to be accorded to what he has to say; differences in the discourse function of different parts of what he says - 'textual' or 'organizational'; and the role he wishes to play vis-a-vis his interlocutors. (Holes, 1991, p.20)

\section{DISCUSSION}

After salient portions of the taped conversations were transcribed, the language of the informants was compared and contrasted, in view of answering the questions posed in the purpose section above. Analysis was then made to determine which varieties of Arabic (and which accommodation strategies) were used by particular speakers in particular combinations with speakers of other varieties of Arabic.

\section{A. Diglossic Code-switching and Linguistic Accommodation}

As the examples below show, these educated speakers of Arabic, when conversing with one another in informal conversational interactions, did not necessarily use a particular variety of Arabic as a lingua franca, but rather employed a number of linguistic accommodation strategies such as switching between the different varieties of Arabic-both colloquial and Standard varieties.

The following example, from a conversation between the Saudi Male and the Moroccan Male, indicates switching from ESA to MSA.

Example 1: SM and MM

SM:

1. binnisba 1i SaaPilatak wa wujuudhaa maSaak In-regard to-your-family and its-presence with-you In regard to your family,

2. hal yuṣraf lahaa

(interrog.) get-paid to-it

do they get paid

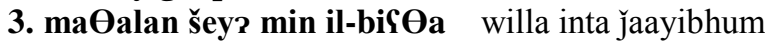

for-example something from the-scholarship? Or you bringing-them

something from the scholarship, for example? Or are you bringing them

4. Sala iłsaabak ilxaas

on your-expense the-own.

at your own expense?

When the Saudi starts talking to the Moroccan, he is not using his own Hijazi colloquial variety, but ESA. The vocabulary in the italicized text preceding the bolded area is basically from the Standard, but with SM's colloquial Saudi pronunciation. Then, in the bolded area, SM switches to MSA - Standard vocabulary and Standard pronunciation. But after the bolded area, the Saudi switches to Saudi colloquial. This example illustrates switching between three varieties 
of Arabic: ESA, MSA, and then Saudi colloquial. The question is what are the functions of the switches here? Apparently, the bolded area is in MSA because it represents the most important part of the text, in particular the question the Saudi male wants answered. He begins in ESA; the pronunciation does not interfere with comprehension as long as the vocabulary items are Standard. This section is more of an introductory nature, more interpersonal. But apparently, the Saudi wants to ensure that the listener, the Moroccan male, understands the question in the bolded area, so he phrases it in MSA. This section is thus more of a textual, or referential, nature (i.e. Holes, 1991), rather than interpersonal. The last part of the statement is really a paraphrase of the main question. It is thus optional; if the Saudi ensures that the Moroccan understands the question posed in MSA, the remainder is more of a comment, and therefore of secondary importance. Thus it is in the colloquial.

The second example is taken from the same conversation between the Saudi and Moroccan males. This time it is the Moroccan Male who is speaking to the Saudi Male.

Example 2: SM and MM

MM:

1. Ћaajaa uxraa ?anaa ?aSrif ?anna kamaan lammaa tị̄iib

Thing another I know that also when you-bring

Another thing I know also is that when you bring

2. Saariltak biyibqaa fii jaanib salbi.

your-family there-remains in-it side negative.

your family there is a negative side to it.

This example begins in ESA, then shifts to colloquial, and then shifts back to ESA again. The two speakers are still continuing the conversation from the previous example, talking about bringing one's family over to the U.S. while at school. The Saudi initiated the discourse, in ESA. It appears that the Moroccan was thus triggered to use ESA in his reply. He switches briefly to colloquial, but then switches back to ESA. Perhaps this switch is intended as emphasis, intended to see that the Saudi notices the message, but can also understand it.

In this entire conversation, both interlocutors employed ESA as the main communicative strategy, generally avoiding colloquial. When switching to colloquial took place, it was only for brief excerpts. This tends to support the position of El-Hassan (1978), in that, for the most part, both speakers chose ESA over either Standard or their respective colloquial varieties. It should be noted that this conversational situation with these two varieties reflects the extreme in both geographical and linguistic distance across the Arabic-speaking world.

One interesting feature of this conversation is the use of what Holes (1991) calls 'hybridization.' He defines hybridization as the matching of a Standard stem with colloquial prefixes or suffixes. In example 2, above, the Moroccan speaker uses the word biyibqaa 'there remains.' The particle $b i$ - is the colloquial imperfect tense prefix in Moroccan colloquial, quite different from the Standard imperfect tense prefix. But the stem -yibqaa is ESA, not Standard-a Standard lexical item, but with some colloquial features in its pronunciation (in this case the first vowel is /i/, instead of the Standard /a/). This particular example illustrates that hybridization is not limited to mixing of elements from the colloquial variety with elements of the Standard, as indicated by Holes' (1991) definition, but can include mixing colloquial with ESA as well.

Another example of hybridization comes from the conversation between SF and JF. They are discussing some of the changes they will have to get used to once again back in their own countries — such as the Saudi law prohibiting females from driving.

Example 3: JF and SF

1. JF: maßnaatu muškili bas tirjạii

It-means problem when you-return?

Is this going to be a problem when you return home?

2. SF: aah ha?aftaqidhaa...ћa?aftaqidhaa bilmarra.

Yes future+I miss it...future+I miss it absolutely.

Yes, I'll miss it...I'll really miss it.

During this part of the conversation both informants used their own colloquial, JF in Jordanian colloquial Arabic and SF in her Hijazi Saudi Arabic. The Hijazi variety of Saudi Arabic shares a large number of phonological and semantic features with Egyptian Arabic. This Western part of Saudi Arabia is located right across the Red Sea from Egypt, and has always had close ties, both economic and cultural, with it. Today, this region can receive radio and television broadcasts from Egypt, and many of the teachers in the schools are from Egypt (as confirmed in table II, below). Hijazi shares more features with Egyptian Arabic than with any other variety of Saudi Arabic. Hijazi and Egyptian Arabic are thus linguistically, as well as geographically, the most closely related two varieties of Arabic used in the study.

In this particular example, JF initiated the exchange in Jordanian colloquial Arabic. SF replies in her Hijazi Saudi colloquial, beginning with a word which is the same in both colloquials. - aah 'yes.' The next word, which in reality is a sentence in itself, is the key point of this example. SF continues into the first part of the word, $\hbar a-$, in her colloquial. This is the future tense marker, and is the same as in Egyptian colloquial. But she switches from that immediately into MSA for the rest of the word, the verb stem (which includes both the first person prefix, indicating the subject, and the suffix which indicates the object of the verb). SF pauses, and then repeats the same thing exactly, but this time along with an 
intensifier, bilmarra 'absolutely'; but bilmarra is in the colloquial. This is in the colloquial because the message really ended after ha?aftaqidha 'I'll miss it.' That answers JF's question; repeating the answer in itself acts as an intensifier, so that another intensifier is redundant. Furthermore, switching to MSA also acts as an intensifier by imparting a scriptural, or textual, nature to the message; this makes bilmarra even more redundant. What SF is doing here appears to be quite similar to what SM did in example 1, above, when he switched to MSA. Here again, MSA is used to highlight the core of the message.

Another example comes from a conversation between the Iraqi Male informant and the Jordanian Male informant. This example illustrates switching between colloquials.

Example 4: IM and JM

IM

1. baððakar qabil-maa saafarnaa lahoon kaan Sinnaa

I-remember before we-travelled to-here was with-us

I remember before we came here we had an

2. duktora mașriyyi fii il-fașil kaanat itguul

professor (f.) Egyptian in the-class she-was says,

Egyptian professor (female) in the class who used to say,

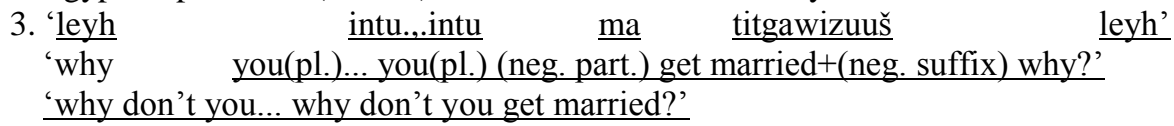

Here, neither of the interlocutors is Egyptian. Nonetheless, IM switches into Egyptian Arabic to quote his Egyptian professor. In this case, apparently he is not using Egyptian Arabic for purposes of linguistic accommodation, but more for a humorous effect. He is using it for a quotation preserving the contextuality of the original statement — which includes the variety of Arabic used by the speaker (Valdes-Fallis, 1978). If IM had not preserved the contextuality, the quotation would have lost its humorous effect. In fact, the quotation contains a miscue on IM's part. He starts out with a word order-leyh intu 'why you'-more Iraqi than Egyptian. Then, he corrects himself and uses a word order more distinctly Egyptian, reversing the order of the two words and placing the interrogative leyh at the end of the question, which is a distinct feature of Egyptian colloquial syntax.

The next example is from a conversation between JF and EF. This example illustrates switching colloquials for linguistic accommodation purposes, with the informant switching first from ESA into the interlocutor's Egyptian colloquial and then into her own Jordanian colloquial.

Example 5: JF and EF

JF:

1. ișsaydalih mumkin itkuun šarlih tijaarriyyih

The-Pharmacology possible it-could-be job commercial

Pharmacology can be a career;

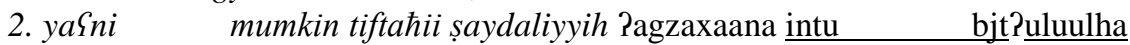

for example possible you-open pharmacy pharmacy you(pl.) call it.

for example, you can open a pharmacy, pharmacy [the term repeated in Cairene Arabic] as you [plural] call it.

In this case, the informant apparently switches from ESA into the interlocutor's colloquial as a means of accommodation. JF subconsciously knows that the word for pharmacy is different in Egyptian colloquial from the word in both Standard and in Jordanian colloquial, so it appears she repeats the word in Egyptian to be sure the listener understands. This is thus a switch for purposes of clarity, accommodating to the listener to see that the listener understands. However, JF then switches into her own Jordanian colloquial afterwards. Perhaps the Egyptian colloquial triggered a switch here, or it is simply an afterthought, spoken as much to herself as to EF. In any case, the section in Jordanian is of secondary importance, as the important part of the utterance was up to the Egyptian word for pharmacy. This secondary degree of importance doubtlessly has a bearing on the switch as well, as in SM's switch into his Saudi colloquial in example 1 above. The main message ended then. Also, in this case the section in Jordanian colloquial Arabic is intelligible to EF, as she has shown that she does understand Jordanian colloquial, so miscomprehension is not a factor.

The following example also comes from the conversation between JF and EF. Here EF speaks to JF. JF's uncle is going on an extended hunting trip to Canada, and his wife, who is expecting, is going back to Jordan to visit. EF is curious about where JF's aunt is going to have her baby.

Example 6: EF and JF

1. EF: țab kiif hatxallif hoon?

So how [future] give birth here?

So will she have the baby here [or in Jordan]?

2. JF: laa hoon.

No, here [not in Jordan].

No, here [not in Jordan].

3. EF: hoon.

Here. 
Here.

Here, EF asks JF about where her aunt plans to give birth. EF begins in her native Egyptian colloquial, but then she says hoon here, in Jordanian Arabic instead of the Egyptian hinaa 'here.' Then she repeats it after JF's answer, again in Jordanian. It should be noted here that not only is EF speaking to a Jordanian, but also about another Jordanian. It would have made no difference in comprehension if EF had said hinaa instead of hoon. JF would still have understood. While EF might have picked up the term from a Levantine teacher (the term LEVANT generally refers to Syria, Lebanon, Jordan, and Palestine), or while living in the UAE (where hoon is also used), in other parts of this conversation and in conversations involving other interlocutors she still uses hinaa regularly. Therefore this is not a borrowing into her variety of Arabic, but a code-switch. Likewise, there is no communicative need for the switch, such as improving comprehension. However, there are two possible reasons. One likely reason is that by switching varieties, EF has emphasized location, making that the salient topic of the conversation. The other possibility is simply that EF is attempting to converge toward JF, since JF has exhibited a willingness to use Egyptian. However, this incident could just as easily qualify as what Valdes-Fallis (1978) refers to as "random switches of high frequency items at the word level" (p.16).

The following example comes from the group conversation involving all Eve females. The first one who speaks is EF, in Egyptian colloquial.

Example 7:

1. EF: xalaaș ha?uul haaga.

Enough [I + fut. Prefix] say something.

Okay, I'll say something.

2. JF: ?uuli yaa.. rašaa ilyuum maa

[2nd person imp.] say [vocative] Rasha today [neg particle]

Yes, say something, Rasha, you haven't said

3. Pultiǐs

[you] said [past tense] [neg suffix] something at all

anything at all today.

This is at the very beginning of the group conversation, when all the informants are waiting to see who will start first, and what the topic will be. Here, EF chooses to start the conversation, and she chooses to speak in her own Egyptian colloquial, not ESA, MSA, or another variety. JF replies, beginning with her own colloquial. The first word of the sentence resembles Egyptian, but it is a feature of JF's own variety of Jordanian Arabic as well, so it cannot positively be identified as a code-switch. Perhaps because of this ambiguity, JF is not triggered into Egyptian, but is given the option of choosing to continue in Jordanian, which she does. From this point up to the last two words, the sentence is clearly in Jordanian Arabic. However, the last two words are just as clearly in Egyptian Arabic. The word ћaaga 'something,' borrowed from EF's utterance, is both lexically and phonetically Egyptian. JF then continues in Egyptian instead of going back to Jordanian. The word xaaliṣ 'at all' is derived from the same root as the word xalaas 'enough' used by EF, and is likewise uniquely Egyptian. This Appears to be a play on words, exchanging ћa?uul haaga '[I will] say something' for maa ?ultiiš haaga xaaliṣ '[you] haven't said anything at all.' It is thus necessary for JF to remain in Egyptian to make this play on words. If she had not used EF's own colloquial, the play on words would not have the force it does, because it would not have been a clear quotation of EF's statement. JF must maintain contextuality to make her joke work. Otherwise, if it had been spoken entirely in Jordanian, it could have seemed like a simple statement, and could have even been interpreted as offensive by EF and possibly the other interlocutors. By code-switching into Egyptian, JF has avoided the possibility of her remark being interpreted as anything other than a humorous remark.

The last example, example 8, comes from the conversation involving all five male informants. The Saudi male is asking the Jordanian male about the cost of higher education in Jordan. SM assumes that higher education is free in Jordan, just as it is in Saudi Arabia, and asks JM to confirm that.

Example 8: SM and JM

$\begin{array}{lcc}\text { 1. JM: laa bilsaks ittaSliim } & \text { muškilih fii } & \text { ilurdun. } \\ \text { No, in-the-opposite the-education problem } & \text { in the-Jordan. }\end{array}$

No, on the contrary, getting an education is a problem in Jordan.

2. SM: laa!

No!

No!

3. JM: aah raali wallah
yes expensive by-God Yes, it's expensive!

4. JM: yaSni halla? batwaqqaৎ ilwaði؟ I-mean now I-expect the-situation reached to-stage that I mean now I think the situation has reached the point where

5. i1taCliim reyr maftuuh illaa the-education not open except education is not available except 


\section{LIMAN ISTATTAASA ILAYHI SABIILAA TO-WHOMEVER COULD TO-IT WAY. \\ FOR THOSE WHO CAN AFFORD IT.}

In this conversation, the topic appears to be driving the variety choice. Education is being discussed, and JM chooses ESA to discuss it (cf. ErvinTripp's, 1968 discussion of factors influencing code choice). SM's exclamation is likewise in ESA, when JM does not confirm his assumption. Then JM restates what he has just said, paraphrasing it in Jordanian colloquial. Here, in an exclamation, JM temporarily 'steps outside of the conversation,' and using his own variety makes it more expressive. Then, JM begins the next sentence with a 'filler,' yaSni 'you know'. This is what Valdes-Fallis (1978) describes as a switch involving a pre-formulation, such as a linguistic routine or automatic speech-discourse markers (p.16). But the topic immediately drives the variety back to ESA as soon as the exclamation and discourse marker are passed. But then, in the middle of his sentence, JM switches from ESA on into MSA. There appear to be several reasons why he does it. First, the point spoken in MSA is the central point to this conversation. Giving it in MSA makes this clear, not just to SM but to all the interlocutors present. This is what Holes (1991) refers to as giving a scriptural quality. Second, it adds emphasis to the seriousness of the situation with higher education in Jordan. Next, the statement includes a paraphrase of the teachings of the Prophet Mohammad, comparing getting an education today with the Prophet's teachings on the difficulties of making a pilgrimage to Mecca. The last four words of JM's statement - LIMAN ISTATAASA ILAYHI SABIILAA 'except for those who can afford it' — are an exact quote from the Prophet. This in itself would require a switch into the Standard, in fact into the Classical Arabic of the Qur'an. So actually, even though these words are still used in MSA, it could be said that JM then switches from MSA into CA. Finally, this play on words (almost bitter, in a way) from JM would in itself require some highlighting (as in JF's play on words in the previous example), and switching varieties is one way to do that. Laughter from the other interlocutors indicates that the play on words does achieve the wryly humorous effect intended by JM.

\section{CONCLUSION}

The assertion that educated Arabs from different countries generally speak Classical Arabic to one another when their native varieties are not the same or may not be mutually intelligible (Bateson 1967; Grosjean 1982; Katzner 1986), thus does not appear to be accurate. As noted by Ferguson (1963), different varieties of the language exist, side by side, each with its own purpose. Speakers will use these varieties depending on the conversational setting; e.g., CA and MSA are used during some formal university lectures, formal speeches, sermons, and so on, while colloquial Arabic is spoken in less formal situations such as giving examples and explanations, or in meetings and conversations. However, it appears that diglossic code-switching is an unmarked rights and obligations set (Scotton, 1983) among these educated Arabs. Diglossic code-switching appears to be the normal, even expected, behavior among these informants.

Likewise, however, El-Hassan's (1978) statement that these speakers use ESA as a common variety, instead of CA, does not necessarily hold true either. They may use ESA when their colloquial varieties are linguistically and geographically distant, and thus not mutually intelligible, or if the topic necessitates more Standard language, but these speakers may also employ other varieties freely as well as previously discussed in Abu-Melhim's (1991) study, and most recently in (Bianchi, 2013) and (Myers-Scotton, 2013).

While the subjects did switch to MSA, apparently it was used only for purposes of clarity and comprehension, as well as for accuracy in quoting and in providing emphasis, not as a conversational medium. (Examples 1 and 3, above, demonstrate this). As Gumperz (1982, p.75-78) notes:

In many instances the code switched passages are clearly identifiable either as direct quotations or as reported speech...Frequently a message in one code is repeated in the other code, either literally or in somewhat modified form. In some cases such repetitions may serve to clarify what is said, but often they simply amplify or emphasize a message.

Rather than relying primarily on CA or MSA, the informants employed a variety of accommodation strategies when conversing with one another, including using ESA, switching between ESA and the colloquial, and switching between colloquials.

However, when these functional necessities behind a speaker's code-choice are not necessarily the driving factor, other factors come into play. These factors are related to the concepts of one's personal identities (including national, ethnic, and religious identities and so forth) and one's need for power and control. This seems to be interrelated with one's concept of personal identity, and may derive from it. For example, MF's (apparently accurate) perceptions about the status of Morocco and its colloquial in the Arab world, with its corresponding effects on her personal identity, apparently led her to attempt to gain control so as to negotiate a rights and obligations set which would establish her variety and herself on an equal basis with her interlocutors and their varieties.

All types of code-switches were used, from the word to the sentence level. A good example of an intra-word level switch is in example 2, where MM uses a hybridized form consisting of an ESA verb stem and a colloquial prefix and in example 3, where SF uses a hybrid of a Hijazi Saudi prefix and an MSA stem. This is not a code-mix because data suggest that this is an accepted form in educated speech (Eid, 1982 \& Holes, 1991). The use of the same word in two different colloquials in example 5 illustrates the word-level switch, as well as a phrase-level switch following it. Example 1 illustrates both clause and sentence level switches. 
Very little colloquial was used during that time. When the topic changed again, the informants began switching to other varieties once more. Hence, the conversational interaction among these speakers of different varieties of Arabic involves a variety of accommodation strategies, each used for a specific purpose and social meaning. Apparently, the variety one speaks is not the major factor here, but one's willingness to accommodate in order to achieve successful communication. The major goal of code-switching in the conversations appears to be that of clarity of communication. This parallels Shaaban's findings:

...the main aim of the individual is to get the message across to others rather than to sound sophisticated; if a certain dialectal feature, like negation, is shared by other speakers, no attempt is made to use an FA feature instead. Only when a speaker thinks that the others do not have the same items as his dialect does he try to find the same item in FA. (1978, p.13)

This success in communication in part appears to revolve around perceptions and attitudes. An interesting corollary to this is that when informants expressed uses of code-switching for other than communicative purposes, such as not wanting to sound different (EM), or because they like the way the language sounds (JM), they were less successful. Thus to claim that CA and MSA are the varieties of Arabic speakers use to facilitate comprehension appears to be inaccurate and does not consider the availability of other linguistic resources speakers rely on when involved in informal conversational settings.

\section{REFERENCES}

[1] Abu-Melhim, A. (1991). Code-switching and linguistic accommodation in Arabic. In B. Comrie \& M. Eid (eds.), Perspectives on Arabic linguistics III. Amsterdam, Philadelphia: John Benjamins, 231-250.

[2] Bahous, R. N., Nabhani, M. B. \& Bacha, N. N. (2013). Code-switching in higher education in a multilingual environment: a Lebanese exploratory study. Language Awareness 22.3, 197-213. DOI: 10.1080/09658416.2013.828735.

[3] Bateson, M. C. (1967). Arabic language handbook. (No. 3 in the Language Handbook Series). Washington, DC: Center for Applied Linguistics.

[4] Bell, A. (1984). Language style as audience design. Language in Society 13.2, 145-204. DOI: 10.1017/S004740450001037X.

[5] Bell, A. (1982). Radio: The style of news language. Journal of Communication 32.1, 150-164. DOI: 10.1111/j.14602466.1982.tb00486.x.

[6] Bianchi, R. M. (2013). Arab English: The case of 3arabizi/Arabish on Mahjoob.com. Voices in Asia Journal 1.1, 82-96.

[7] Blanc, H. (1960). Style variations in Spoken Arabic-A sample of inter-dialectal conversation. In C. Ferguson (ed.), Contributions to Arabic Linguistics. Cambridge, MA: Harvard Middle Eastern Monographs, 81-156.

[8] Bres. J. \& Franziskus, A. (2014). Multilingual practices of university students and changing forms of multilingualism in Luxembourg. International Journal of Multilingualism 11.1, 62-75. DOI: 10.1080/14790718.2013.831098.

[9] Caporael, L. R., Lukaszewski, M. P. \& Cuibertson, G. H. (1983). Secondary baby talk: Judgments by institutionalized elderly and their caregivers. Journal of Personality and Social Psychology 44.4, 746-754. DOI: 10.1037//0022-3514.44.4.746.

[10] Eid, M. (1982). The non-randomness of diglossic variation in Arabic. Glossa 16.1, 54-84.

[11] El-Hassan, S. (1978). Variation in the demonstrative system in educated spoken Arabic. Archivum Linguisticum 9.1, 32-57.

[12] Ervin-Tripp, S. (1968). An analysis of the interaction of language, topic, and listener. In J. Fishman (ed.), Readings in the sociology of language. The Hague: Mouton, 192-211.

[13] Ferguson, C. A. (1963). Problems of teaching languages with diglossia. In A. Dil (ed.), Language structure and language use: Essays by Charles A. Ferguson. Stanford, CA: Stanford University Press, 71-86.

[14] Ferguson, C. A. (1959). Diglossia. Word 15.2, 325-340. DOI: 10.1075/lplp.3.3.08fer.

[15] Giles, H., Coupland, N., \& Coupland, J. (1991). Accommodation theory: Communication, context, and consequence. In H. Giles, N. Coupland, \& J. Coupland (eds.), Contexts of accommodation. New York: Cambridge University Press, 1-68. DOI: 10.1017/CBO9780511663673.001.

[16] Giles, H., \& Bradac, J. J., Johnson, P., \& Mulac, A. (1987). Speech accommodation theory: the first decade and beyond. In M. L. McLaughlin (ed.), Communication yearbook 10. Newbury Park, CA: Sage Publishers, 13-48.

[17] Gottman, J. M. (1982). Emotional responsiveness in marital conversations. Journal of Communication 32.3, 108-120. DOI: 10.1111/j.1460-2466.1982.tb02504.x.

[18] Grosjean, F. (1982). Life with two languages. Cambridge, MA: Harvard University Press.

[19] Gumperz, J. J. (1982). Discourse strategies. Cambridge: Cambridge University Press. DOI: 10.1017/CBO9780511611834.

[20] Holes, C. D. (1993). The uses of variation: A study of the political speeches of Gamal Abd Al-Nasir. In M. Eid \& C. D. Holes (eds.), Perspectives on Arabic linguistics V. Amsterdam, Philadelphia: John Benjamins, 13-45.

[21] Juma, M. J. (2013). A Sociolinguistic perspective to Arabic and Arabs virtual communities with special reference to the Shi'a as a religious minority in the Arab world. International Journal of Virtual Communities and Social Networking 5.1, 19-4. DOI: 10.4018/jvcsn.2013010102.

[22] Katzner, K. (1986). The languages of the world. New York: Routledge, Chapman and Hall. DOI: 10.4324/9780203430163.

[23] Kaye, A. S. (1990). Arabic. In B. Comrie (ed.), The world's major languages. New York: Oxford University Press, 664-685.

[24] Labov, W. (1972). Sociolinguistic patterns. Philadelphia: University of Pennsylvania Press.

[25] Mitchell, T. F. (1986). What is educated spoken Arabic?. International Journal of the Sociology of Language 61.1, 7-32. DOI: 10.1515/ijsl.1986.61.7.

[26] Myers-Scotton, C. \& Jake, J. L. (2013). Nonfinite verbs and negotiating bilingualism in codeswitching: Implications for a language production model. Bilingualism: Language and Cognition 16.4, 1-15. DOI:10.1017/S1366728913000758.

[27] Myers-Scotton, C. (1986). The Diglossia and code-switching Fergusonian impact: in honor of Charles A. Ferguson on the occasion of his 65th birthday. In .J. Fishman, A. Tabouret-Keller, M. Clyne, B. Krishnamurti, \& M. Abdulaziz (eds.), Sociolinguistics and the sociology of language Volume II. Berlin: Mouton de Gruyter, 403-415. 
[28] Myers-Scotton, C. (1983). The negotiation of identities in conversation: A theory of markedness and code-choice. International Journal of the Sociology of Language 44, 115-136. DOI: 10.1515/ijsl.1983.44.115.

[29] Shaaban, K. A. (1978). Code-switching in the speech of educated Arabs. Journal of the Linguistic Association of the Southwest 3.1, 7-19.

[30] Valdes-Fallis, G. (1978). Code-switching and the classroom teacher. Language in education: Theory and practice, series no. 4. Washington, DC: Center for Applied Linguistics.

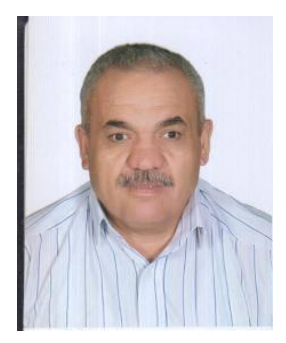

Abdel-Rahman Abu-Melhim was born on February 14, 1958 in Jerash, Jordan. He is a Jordanian-American, currently teaching as an Associate Professor of English language and literature at Al-Balqa'a Applied University in Jordan. He graduated from Texas A\&M University, College Station in 1992. His Ph.D. degree was in English with emphasis on Socio-linguistics. His research interests include: Socio-linguistics, Applied Linguistics, Psycho-Linguistics, and Cross-Cultural communication. 